\title{
CYTOTOXICITY INDUCED BY ALPRAZOLAM IN RAT VITAL ORGANS
}

\author{
Nadia A. Abdelmajeed and Amanl M Manaa \\ Department of Blochernstry, Girls college of Eduration . \\ king Abchulazlz University Jeddah. Kngdom of Saudl Arabja \\ P.O.Box 50098 Jeddah 21523
}

\begin{abstract}
The current study demonstrated the cytotoxic effects of alprazolam on the vilal or. gans of rals. Animals were divlded into two groups; Gi: normal control (ntol received any diug), G2: alprazolam treated group. Alprazolam was ingested orally using a single dose of $1 \mathrm{mg} / 100 \mathrm{gm}$ body weight. The effects of this drug toxkity on different tissue vilol organs thssues (llver. Kidney and heart) were studicd after 10,20 and 30 days from drug administration. The results revealed that administiution of alprazotam utuces axdative thssue damage indicated by significant increase in the activity of xanthine oxidase (XO) with concomitant elevated level of nitric axde (NO) in liver, kldney and heart of alprazolam -treated rats in comparison with normal animals. The increment of such oxtdatue thssue damage morkers was accompanied by ucreased malondialdehyde (MDA, index of lipid peroxidation) in kidney, and decrease in adenosine triphosphatase (ATPase) and lactate dehdrogenase (LDH) activities in cardlac tissue. The oxddative thssue damage induced in liver in iesponse to alprazolam ingestion was supported by a depletion in the activity of hepulic sorbitol dehydragenase (SD) coupled with elevation in serum enzymes, aspartate umunotransferase (AST), alanine aninotransferase (ALT) and gamma-glutanyl traisferase (GGT) / indices of liver functton ). Also the obvtous increase of scrum makers of kidney. creatinine and uric acld levels as well as the increase in serum marker enzyme of heart, creatine phosphokinase (CPK) in alprazolam treated animals versus normal ones, vidicating cardtorenopathy. Moreover. investigation also revealed that ingestion of alprazolam to rats led to decreased level of hemoglobin (AH) compared with normal animals The deteriorations in the biochemical results were severe in 20 and 30 days after the drug administration and documented by the histopathological pictures of the studled organs.
\end{abstract}

Key wonds; alprazolum cytotaxicty, tissue damage. histopathological pictures, entzymes.

\section{INTRODUCTION}

In the last fow decades, the exponentlal inrrease in the use of powerfu! pharmacological agents has Icd to Increased eoncerns about drug-induced adverse health cvents (Stregg. 2001). Pre-marketing clinical trals provide concluslve information on drug effectuveness. but typlcally they are underpowered for de- 
tecting adverse effects. Carefully designed and analyzed large-scale epidemlologlcal positmarketing surveillance studies are therefore essential to establish the assoclations between drugs and adverse reactions (Abrahamowhez et al., 2006).

Benzodiazepines (BDZs) are widely prescribed for the chrontc treatmont of epllepsy and panie disorders. Alprazolam is a member of $\mathrm{BD} Z \mathrm{z}$ group of drugs. widely used as ant psychotic and anxiolytic agent (Isbigter et al., 2004; Moroz 2004). However, Patlents usin!s this diug report benzodiazeplne related adverse events, such as drowsiness, dlzzinessi, and redueed alertness (Verster and Volkerts 2004). In addition a vast amount of studies have shown that alprazolam in doses of 0.5 $\mathrm{mg}$ and higher Induce changes in brain oxddatwe nietabollsm and impalrs a varlety of eognitive and psychonotor skills such as memory impairment. speed of rcsponscs. trackung perfomance and a considerable potentlal to induce dependence and abusc (Verster and Volkerts 2004; Pardo et al., 2006: Leu(kens et al., 2007). It also induces conformational changes lil hemoglobln (Mattra et al.. 2007) and intercalates into the DNA (Saba et al., 2009a). In addition, it vias found that alprazolarn produced severe cytotoxdcity in human cell thes as it Induced elevated level of rcactive oxygen specles (ROS) and depletion of antioxidants (Saba et al., 2009b). Generally. It was reported that all benzodlazeplnes drugs can cause respiratory dcpresslon (Woodcock et al., 1981). hepatic dysfunction (Ananth et al., 1994). Hypotension and thrombophlebits (Donaldson and Glbson. 1980; Glaser et al., 1982), brain damage (Meador, 1994).
None of the previous studies investlgated the pathological effects of these drugs on different organs in experimental animals. so the objective of this investigation is to study the efferts of alprazolam in inducing oxidatlve tissue injury on rat liver, kidney and heart.

\section{MATERLALS AND METHODS Chemlcals:}

All chemieal reagents were of analytical grades purchascd from SIgma Chemical CD. (St. Louls. Mo, USA), Merk (Germany) and BDH (England). Dlazepam diug was obtained from Swiss Holman Laroch Limsted Company.

\section{Animals :}

60 adult male albino rats (100-120gm) were obtalned from animal house. King Fahed Center for Mcdicinal Research. King AbdulAzlz Unlversity, Jeddah. The anlmals were housed in cages under standard hyglenic conditlon and were fed with rat chow and water ad libitum. In order to optimize drug absorption. All animals were fasted for 1 hour prior to drug administration.

\section{Experimental Design :}

Rats were divided into Two groups normal healthy group (group 1) and drug treated group (group 2), each of 30 rats. Alprazolam drug was administered orally using a single dose of $1 \mathrm{mg} / 100 \mathrm{gm}$ body weight (Leufrene et al., 2007). The effect of this drug toxicity on different tissue organs (liver, kidney and heart) was studled alter 10,20 and 30 days from drug ingestion. After each studied pertod the blood samples were eollected from antmals into sterlized tubes for serum separation and into tubes contalning heparin for hemoglobin determination. Serum was 
separated by centrifugation at 3000 _ g for 10 minutes and used for blochemlcal analysis. At the end of each expcriment, rats of each experimental perlod were sacrifled under ether anesthesla and the liver, kddney and heart samples were collecked. minced and homogcnized in elther ice cold bidistilled water or $10 \%$ to yield $10 \%$ homogenates using a glass homogenizer. The homogenates were centrifuged for 15 minutes at $10000 \mathrm{~g}$. at $4^{\circ} \mathrm{C}$. and the supematants and used for different blochemical tissue analysis.

\section{Blochemical analysts :}

All the following blochernical paramcters were measured spcctrophotometrically .

\section{Tissue analysis :}

Nitrite concentration (an indlrect mcasurcment of NO synthesis) was assayed using Gitess reagent (sulianllamide and $\mathrm{N}$ - lnaphthylethylcnedlamine dlhydrochloride) in acldic medium (Moshage et al., 1995). Llpld peroxidation was determined by measuring the formed MDA (Buege and Aust. 1978). XO actuvity was determined by the reduction of nitroblue tetrazollum (NBT) (Frled and Frled. 1974). ATPase was detcrmined using the method of Tsakiris and Deliconstantunos (1984). LDH acuvity was evaluated according to (Bergmeyer, 1976). Sorbltol dehydrogenase was measured by the method of Bergmeyer (1974).

\section{Serum analysis:}

ALT and AST actulties were determined aceording to the inethod described by (Bergmeyer et al., 1986). Gamma Glutamyl Trans ferces [GGT] was measured by the method described by Shaw et al. (1983), unc Acld
(UA) by the method described by Bulgar and Johns (1941), creaunine (Crea) by the method of Larsen (1972) and creatune phosphoktnase (CPK) by the method destribed by Rosal. $\mathbf{k}$ (1967). GGT was assayed by the method of Schmldt and 8chmldt (1981).

\section{Blood analysls :}

Hb was estlmated in the whole heparinlzed blood by cyaninethaemoglobin method (Drabkin and Austin, 1932).

\section{Histological evaluation :}

Representative slices from liver, kddney and heart Ussucs were taken from the evlscerated animals and fixed in $10 \%$ formalin. For light microscopy examination, the ussues wcre embedded in paraflin, sectlomed at 5 _ $\mathrm{m}$ and stalned with hcmatoxylln and eosin (H\&E).

\section{Statigtical analyees:}

Data wcre analyzed by comparing values for different treatment groups with the values for Individual controls. Results are expressed as mean \pm S.D. The significant differences among values were analyzed using analysis of varlance (one-way ANOVA) coupled with posthoc (LSD) and followed by Bonferonl as a post ANOVA test (Evans and O'Connor, 2007).

\section{RESULTS}

Oxidative tissue injury markers in different tissue organs in normal and alprazolam treated groups after the three studled different pertuds are shown In cable (1). Alprazolam administration to rats led to markcd elcvated actuvity of xanthin oxidase (XO) with concomltant increase in nitric oxide (NO) level In liver, kddney and heart of alprazolamtreated rats compared with normal one. The 
elevation of such markers was accompanled by reduction in the activity of sorbitol deny. drogenase (SD) II liver. elevated level of mal ondlaldehyde (MDA) in kudney and depletton in adenosine triphosphatase (ATPase) and lactate dehdrogenase (LDH) activitles in heart tissue. Table (2) shows the levels of blood functional markers in nomal and alprazolam treated rats after three studled different perlods. The results revealed tncreased in liver function marker enzymes. senum aspartate aminotransferase (AST), alanine amlnotrousferase (ALT) and ganma-glutamyl transferase (GGT). Marked increment of serum markers of kudney function, creatinlue and unc acid levels and increase in serum markcr enzyrre of heart, creatune phosphokinase (CPK) in alprazolam treated animals versus normal ones wcre also observed. The table also shows that administration of alprazolam to rats lcd to di creased level of hemoglobin (Hb) in alprazolam treated animals compared with nomal arijmals. The histopathological pictures of ilver. kiduey and heart of alprazolam treated anumals were observed in figures 1.2 and 3 rcspectively. The pictures showed severe: necrotuc degenerative changes in the Uver and kidney in rats treated with alprazolam. Inflammation and necrotic changes in the muscle flbres of hearts of antmals under the effect of the used drug was also observed. These changes werc severe in 20 and 30 days after the drug ingestion.

\section{DISCUSSION}

The benzodlazepines (BZs) are still the most widely used anxiolytic compounds. Howcver. recent study demonstrated that these drugs have serious toxtc effects (Saha et al.. 2009b). The current investigation was de- signed to evaluate the undesirable toxic effccts of alprazolam which is a member of RD7s group of drugs

Administration of alprazolam drug to rats induced oxidatlve tissue damagc in different organs of rats which was proved by obvious Increment in the activity of free radical producing enzyme. XO accompanled by elevated NO level In livers, kidneys and hcarts of alprazolam treated rats in compared with normal animals. The increment of such blomarkers was accompanied by Increased MDA in kidrsey, and decreased in ATPase and LDH activities in heart tissue suggesting that liver. kidney and heart are target organs for alpraz olam toxicity. Our results agree with prevlous study stated that this drug produeed severe cytotoxicity in human cell lines as It Induced elcuatcd level of rcactlve oxygen specles (ROS) and depletlon of antloxidants (Saba et al. 2009b).

Chronic and acute overproduction of ROS under pathophysiologlc conditions forms an integral part of the development of Lver, kidney as well as cardlovascular diseases NIctor et al., 2009; Hinson et al.. 20 10: Zhang et al., 2010). XO is one of the oxddases enzymes which have the major role in the production of ROS and reactive nitrogen species (RNS) that can produce oxldative Ussuc injury CHarrlson 2002; Fadilloglu et a.. 2003; Victor et al., 2009) . It catalyzes the reduction of nitrite to NO which has varlous pathological dangerous effects on different Ussues (Mohamed et al., 2001; Gao, 2009).

Nitric oxdde (NO) exerts a broad range of effects on bodily functions including muscle 
contractulity, platelet aggregation, metabolisin. neuronal activity, and immune responses. The underlylng mechanisms rely primarlly on elevaling guanostre 3'.5'-cyclic monophosphate due to the sumulation of soluble guanylyl cyclase. Inhlbrting mitoehondria rcspiration by the action on cytochrome $\mathrm{C}$ oxidase, and nitrosylating proteins and enzymes. Under pathophysiological conditions, an increased production of NO concurrently with an enhanced generation of superoxide leads to the fumbition of peroxynitrite, a potent oxidative agent, and thus tissue injuries (Gao, 2009). Productlon of peroxynitrite was found coupled with oxtdzing cellular structure and causes lipld peroxidation (Welnsteln et al., 2000; Sayed Ahmed et a.. 2001) Lipld peroxdation and lípidradieal cycles are two alternative processes. These cycles activate mernbrane protelns, protect membrane liplds from oxldation and prevent from formation of endogenous aldehydes. Expermental and clinical evidence suggests that production of endogenous toxlc aldehyde. such as MDA is the major inttiators of the metabolic alterations (Dmitriev and Titov. 2009).

ATPase is an Important membrane bound enzyme that is direclly involved in energy couversion and has an important role in maintaining the integrity of the myocardlal inembrane (Devila and Matnzen Prince 2008). The reduction in such enzyme may artributed to the ability of alprazolam to Induee upid peroxidation which has dcleterious effects on the eell membrane and coupled with inactivaton of membrane-bound enzymes (Hazarika and Sarkar 2001). A significant fall in $\Lambda$ TTase activity of rat hearts in response to alprazo. lum treatment may lead to a decrease in metabolic energy tumover due to toxlc effects of alprazolam.

The present work revealed that the coxic dangerous effects of alprazolam induced in livers of alprazolam treatcd rats was documented by a decrease in the activity of hcpatic SD coupled with increase in llver serum marker encymes, AST, ALT and GGT. This result was supported by previous clinical stud. les stated the complex interaction between hepatir dysfunction and benzodiazepines treatment which may directly contribute to hepatic encephalopathy. (Ananth et al., 1994). The abnormalittes in such marker enzyrnes activities may be due to the release of these encymes from liver cytosol into the blood stream as a result of tissue damage. caused by alprazolan toxic effect. This result wis also documented by liver histupathologjcal plcture which showed severe damage ensured by severe degcneratlue necrotic changes observed after the three different experimentai perlods. The significant elevated levcls of scrum creatinine and uric acid in animals treated with alprazolam were coupled with deterioratlve clanges in both glomeruli and tubules of kidncy tissue observed in histopathological pictures of animals treated with the used antipsychotic drug and these abnomal changes are well indicators of rcnopathy.

The cardlac tissue damage induced by toxic etfect of alprazolam in rats was ensured by pronounced increased in the aetivity of dIagnostlc serum marker enzyme, CPK and a decrease in LDH of heart tissue in alprazolam treated rats compared to normal ones. This 
was supported by the hitopathological picture of heart tssue which demonstrated inflanmation and myonecrotic lesion of heart muscle libres. These findings conflrm the onset of myocardial leslon and leaking out of the marker enzymes from heart to blood (Ganesan et al., 2009).

Ingestion of alprazolam to rats led to decrcased level of $\mathrm{Hb}$ In alprazolam treated rats compared wh normal animals. This result is coped with previous publlshed data stated that $\mathrm{Hb}$ deflclency In response to alprazolam may be its ablilty to induce conformational changes in hemoglobin (Maltra et al., 2007)
Decreased of $\mathrm{Hb}$ level induced a state of anema which may lead to thrombocytosis which might also related to cardiovascular disease. blochemical abnormallties and impalred ccllmedlated Immunity with increased susceptibllity to infection (Farthlng. 1989; sllverberg et al., 2009)

It could be concluded that, the changes in both blochemical markers and in histological pictures of liver, kudney and heart of alprazolam treated animals leads to suggestion that alprazolam, the antipsychotic drug, might have serious toxic effects on different body organs. 
Table 1 : Oxidative stress markers in different organs of normad and alprazolam treated rats.

\begin{tabular}{|l|c|c|c|c|}
\hline \multicolumn{1}{|c|}{ Parameters } & Normal & 10 days & 20 days & 30 days \\
\hline Liver & & & & \\
\hline XO activity & $3.15 \pm 0.26$ & $25.39 \pm 2.40^{\mathrm{a}}$ & $33.09 \pm 2.29^{\mathrm{a}}$ & $41.15 \pm 2.44^{\mathrm{a}}$ \\
NO activity & $17.30 \pm 1.28$ & $28.09 \pm 2.9^{\mathrm{b}}$ & $37.38 \pm 1.88^{\mathrm{a}}$ & $41.11 \pm 3.34^{\mathrm{a}}$ \\
SD activity & $32.5 \pm 1.60$ & $3.87 \pm 0.45^{\mathrm{a}}$ & $2.82 \pm 0.20^{\mathrm{a}}$ & $2.08 \pm 0.20^{\mathrm{a}}$ \\
\hline Kidney & & & & \\
\hline XO activity & $1.97 \pm 0.26$ & $10.65 \pm 1.48^{\mathrm{a}}$ & $21.73 \pm 1.90^{\mathrm{a}}$ & $28.42 \pm 2.62^{\mathrm{a}}$ \\
NO activity & $5.82 \pm 0.90$ & $28.58 \pm 2.13^{\mathrm{a}}$ & $37.23 \pm 1.43^{\mathrm{a}}$ & $44.12 \pm 3.18^{\mathrm{a}}$ \\
MDA level & $10.17 \pm 1.78$ & $37.41 \pm 2.08^{\mathrm{b}}$ & $54.05 \pm 3.64^{\mathrm{a}}$ & $87.56 \pm 3.24^{\mathrm{a}}$ \\
\hline Heart & & & & \\
XO activity & $2.12 \pm 0.23$ & $12.05 \pm 0.84^{\mathrm{a}}$ & $16.62 \pm 0.52^{\mathrm{a}}$ & $21.95 \pm 1.88^{\mathrm{a}}$ \\
NO activity & $12.40 \pm 2.1$ & $59.16 \pm 2.30^{\mathrm{a}}$ & $70.24 \pm 2.55^{\mathrm{a}}$ & $77.96 \pm 3.16^{\mathrm{a}}$ \\
LDH activity & $5.18 \pm 0.12$ & $2.87 \pm 0.32^{\mathrm{a}}$ & $2.50 \pm 0.22^{\mathrm{a}}$ & $1.28 \pm 0.10^{\mathrm{a}}$ \\
ATPase & $5.06 \pm 0.25$ & $1.56 \pm 0.62^{\mathrm{a}}$ & $2.87 \pm 0.53^{\mathrm{a}}$ & $1.17 \pm 0.22^{\mathrm{a}}$ \\
\hline
\end{tabular}

Data are expressed as mean \pm SD of 8 rats in each group, XO and SD are expressed in $\mathbf{n ~ m o l} / \mathrm{min} / \mathrm{mg}$ protrein, NO is expressed in umol/g tissue, LDH and ATPase are expressed in $\mathrm{u} \mathrm{mol} / \mathrm{min} / \mathrm{mg}, \mathrm{MDA}$ is expressed in $\mathrm{nmol} / \mathrm{g}$ tissue. ${ }^{8} \mathrm{P}<0.001,{ }^{\mathrm{b}} \mathrm{P}<$ 0.01 , when compared with normal group.

Table 2 : Blood functional markers of different organs in normal and alprazolam treated rats after three different periods.

\begin{tabular}{|c|c|c|c|c|}
\hline Parameters & Normal & 10 days & 20 days & 30 days \\
\hline AST $(\mu \mathrm{l} / \mathrm{I})$ & $19 . \overline{57 \pm 2.3}$ & $292.66 \pm 4.32^{* * *}$ & $321.16 \pm 6.63^{* * *}$ & $375.83 \pm 5.67^{* * *}$ \\
\hline $\operatorname{ALT}(\mu \mathrm{l} / \mathrm{l})$ & $17.70 \pm 0.76$ & $70.15 \pm 6.46^{* * *}$ & $82.13 \pm 3.84^{* * *}$ & $91.86 \pm 1.49^{* * *}$ \\
\hline $\begin{array}{l}\text { GGT } \\
(\text { ul } / 1)\end{array}$ & $15.56 \pm 0.69$ & $22.06 \pm 1.78^{*}$ & $24.33 \pm 1.50^{* *}$ & $25.66 \pm 1.75^{* *}$ \\
\hline $\begin{array}{l}\text { Uric acid } \\
\text { (mg/dl }\end{array}$ & $2.60 \pm 0.057$ & $3.47 \pm 0.36^{*}$ & $5 . \overline{41 \pm 0.29 * *}$ & $7.81 \pm 0.72^{* * *}$ \\
\hline $\begin{array}{c}\text { Creatinine } \\
\text { (mg/dl) }\end{array}$ & $0.59 \pm 0.004$ & $4.00 \pm 0.64^{* * *}$ & $6.45 \pm 0.33^{* * *}$ & $9.20 \pm 0.32^{* * *}$ \\
\hline $\begin{array}{l}\text { CPK } \\
(\mu \mathrm{L} / \mathrm{l})\end{array}$ & $30.34 \pm 8.4 \overline{6}$ & $105.00 \pm 4.85^{* * *}$ & $110.5 \pm 4.72^{* * *}$ & $145.66 \pm 11.5 *$ \\
\hline $\begin{array}{c}\mathbf{H b} \\
(\mathrm{g} / \mathrm{dl})\end{array}$ & $16.38 \pm 0.61$ & $12.11 \pm 0.82^{*}$ & $10.88 \pm 0.37^{*}$ & $10.18 \pm 0.56^{* *}$ \\
\hline
\end{tabular}

Data are expressed as mean \pm SD of 8 rats in each group. $P<0.05, " P<0.01$,

"* $P<0.001$ when compared with normal group. 

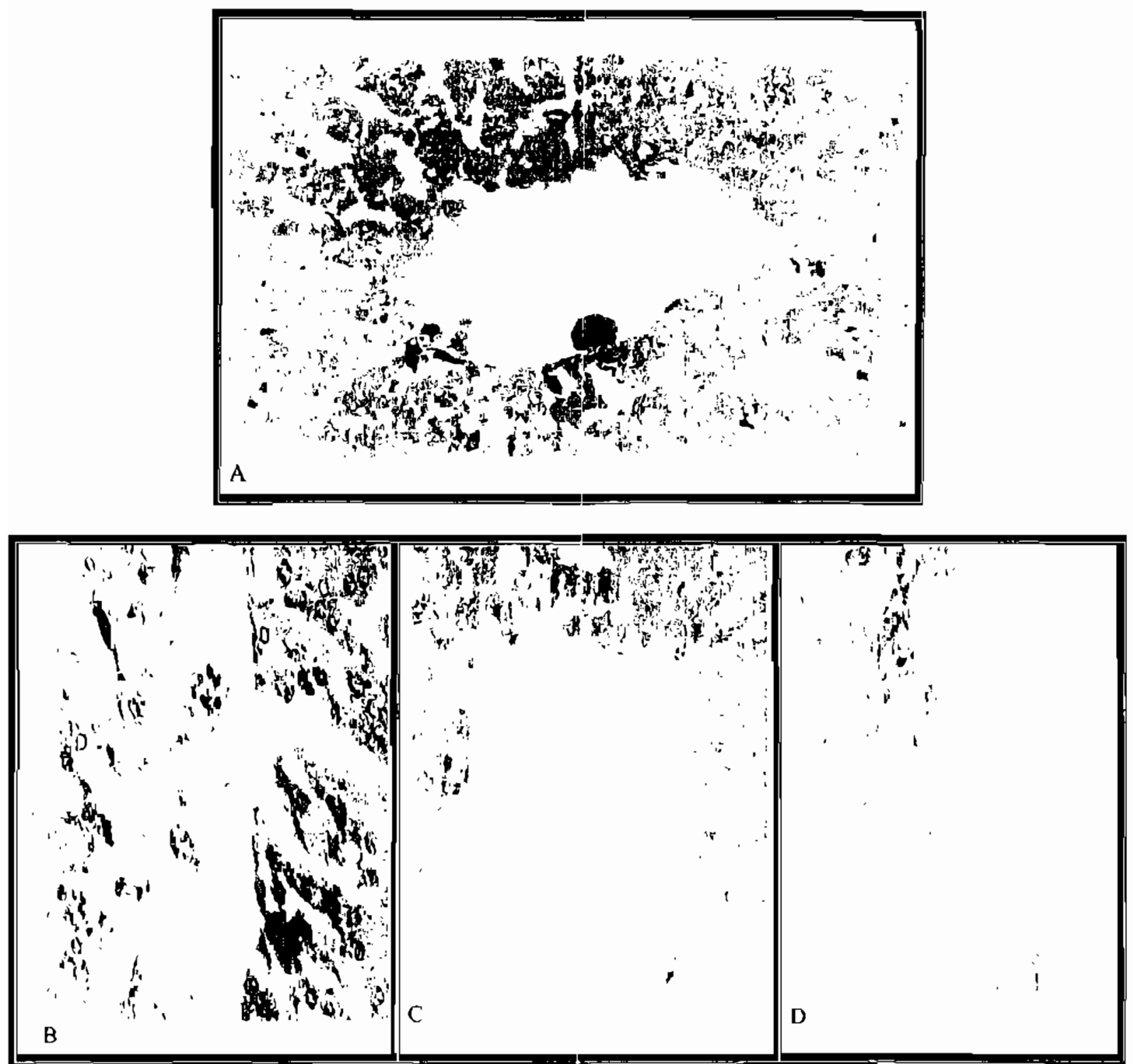

Figure (1) : Effect of alprazolam on liver tissue. A-light microscopic picture of normal liver showing normal hepatocytes B - liver of rats treated with alprazolam after 10 days commenced just after of drug administration, showing loss of liver normal architecture observed by degenerative ehanges in hepitocytes. ( $C$ and $D$ ) - Liver of rats treated with alprazolam after 20 days and 30 days respectively commenced just after of drug administration, showing severe degenerative change in hepatocytcs ( $\mathrm{H} \& \mathrm{E} \times 400)$. 

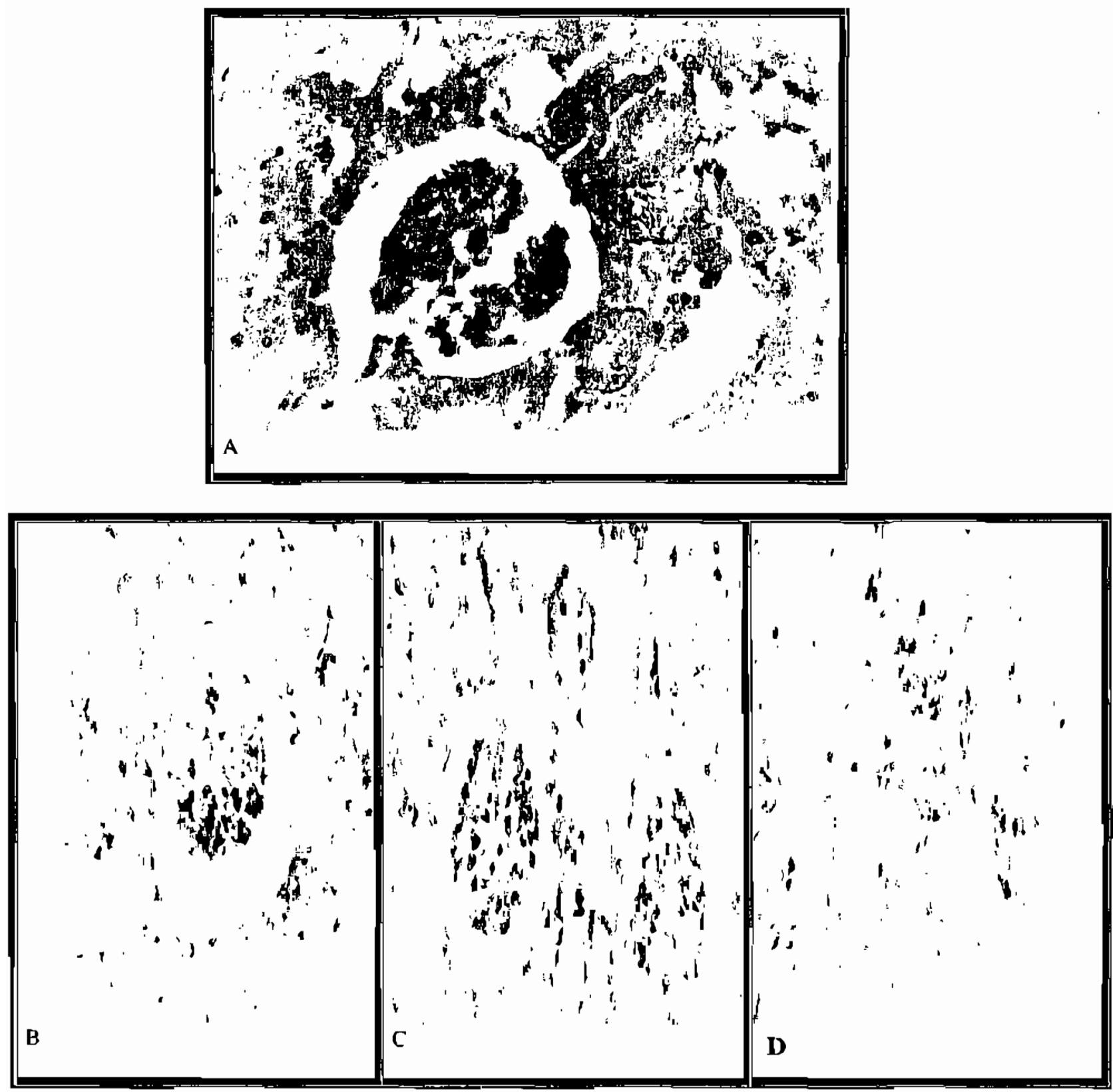

Figure (2): Effect of alprazolam on Kidney Tissues. A-light microscopic picture of nomal kidney showing nonmal tubules and glomeruli B - kidney of rals treated with alprazolam after 10 days, commenced just after of drug administration, showing shrinkage of glomenli, shrinkage of epithelial lining of some tubules and dilation of the lumen of the tubules. ( $\mathrm{C}$ and D) - kidney of rat treated with alprazolam after 20 days and 30 days respectivcly, eommenced just after of drug administration, showing severe degenerative thange in glomeruli and tubules (H\&E $\times 400)$. 

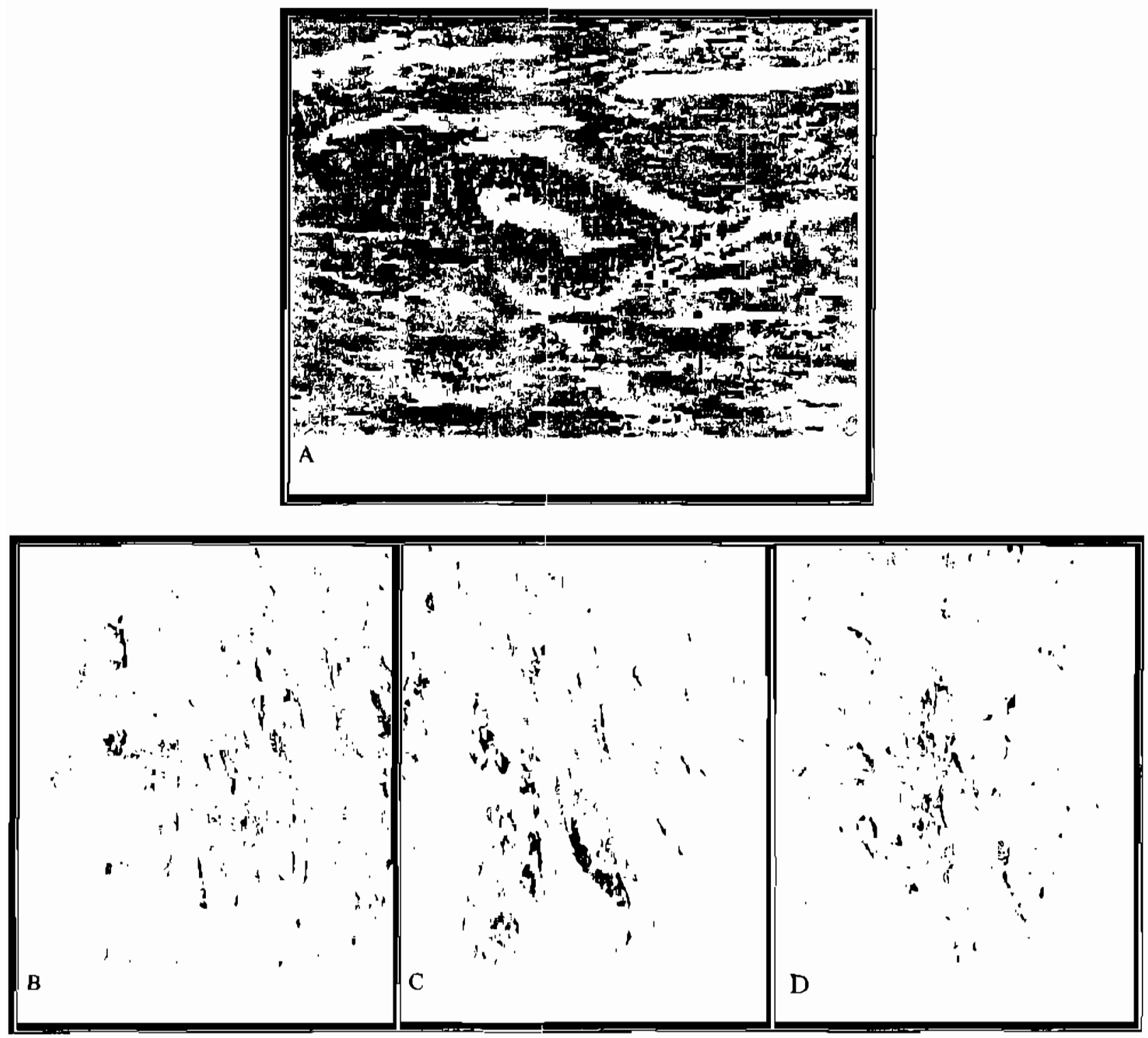

Figure (3): Effect of alprazolam on heart Tissues. A-light microscopic picture of normal heart showing normal muscle fibers B - Heart of rat treated with alprazolam 10 days after drug administration showing necrotic degenerative ehange of muscle fibres in some areas ( $C$ and $D$ ) - Hearts of rats treated with alprazolam 20 days and 30 days after drug administration respectively showing inflammatory cells $(C$ and $D)$ and severe necrotic changes in heart muscle fibers (D) $(\mathrm{H} \& \mathrm{E} \times 400)$. 


\section{REFERENCES}

Abrahamowlcz, M.; Bartlett, G.; Tamblyn, R. and Berger, R. (2006) : Modeling cumulatve dose and exposure duration provided insights regarding the assoclations between benzodlazeplnes and injuries. J Clin Epldemiol. 59. 393-403.

Ananth, J.; Swartx, R.; Burgoyne, K. and Gadasally, R. (1994) : Hepatlc disease and psychiatric lllness: relationshlps and treatmcnt. Psychother Psychosom, 62.146-59.

Bergmeyer, H. U. (1975) : DetermInation of Lactate dehydrogenase. J. Clin Chem Blochem, 13. 269.

Bergmeyer H. U. (1974) : Sorbitol Dehydrogenase. In : Method of Enzymatic Analysts. Eds. Bergmeyer, H. V. Verlag chemtc. Welnhelm. Academic press, New York and London, pp 644- 649 .

Bergmeyer, H. V., Herder, M. and Rej, R. (1986) : Approved recommendation (1985) on IFCC methods for the measurenient of catalyt. ical concentration of cnzymes. Patr 2.IFCC method for aspartate aminotransferase. J Clln Chem ClIn Blochem 24,497.

Buege, J. A and Aust, S. D. (1978) : MIcrosomal lipid peroxidation. Methods Enzymol,52,302-315.

Bulgar HA. Johns HE (1941).The determlnation of plasma uric acid. J Biol Chem , 140 (2) : 427 - 440 .

Devlka, P. T. and Malnzen Prince P. S. (2008) : Eplgallocatechln gallate (EGCG) pre- vents Isoprenalinelnduced cardlac marker enzymes and membrane-bound ATPases. J Pharm Pharmacol. 60:125-133.

Dmitrlev, L. F. and Titov, v. N. 2009) : Lipld peroxldation in relation to ageing and the role of endogenous aldehydes in diabetes and other age-related diseases. Ageing Res Rev (in press).

Donaldson, D. and Gibson, G. (1980) : Systemic complications with Intravenous diazepam. Oral Surg Oral Med Oral Pathol, 49. 126-30.

Drabkin, D. L and Austín, J. M. (1932) : Spectrophotometric constants for common hemoglobin derivatives in human, dog and rabblt blood. J Biol Chem. 98,719-733.

Evans, R. B. and O'Connor, A (2007) : Statstics and ewdence-based veternary med. Icinc: answers to 21 common statistical questions that arise from reading sclentific manuscripts. Vet Clin North Am Small Anim Pract. 37(3). 477-486.

Fadilloglu, E.; Yulmaz, H. R.; Erdogan, H. and Sogut, S. (2003) : The activitles of tissue xanthine oxidase and adenosine deaminasc and the levels of hydroxyproline and nltric oxlde in rat hearts subjccted to doxorubicin : protectuve effect of erdostelne. 'Toxicol, 191,153-158.

Farthing, M. J. (1989) : Iron and Immunlty. Acta Paediatr Scand Suppl:361: 44e52.

Frled, R. and Fried, L. W. (1974) : Xanthine oxidase (xanthlne dehydrogenase). In" 
Methods of Enzymatlc Analysis " 2 nd ed. vol. 2. Bergmeyer HU.ED. Verlag Chemle, Wetnhelm. Academic Press, London, pp. 644649.

Ganesan, B.; Buddhan, S.; Anandan, R.; Sivakumar, R. and Anblnezhlian, R. (2009) : Antloxddant defense of betaine agalnst isoprenalinc-Induced myocardial infarction in rats. Mol Blol Rep (In Press).

Gao, Y. (2009) : The multiple actions of NO. Pllugers Arch (In press).

Glager, J. W.; Blanton, P. L. and Thrash, W. J. (18B2) : Incidence and extcnt of venous sequelae with intravenous diazepam utllizing a standardized consclous sedation technique. I Periodontol. 53.700-3.

Harrison, R. (2002) : Structure and function of xanthine oxddoreduclase :whcre are we now ? Free Radic Blol Med 33.774-797.

Hazarika, A and Sarkar, 5. N. (2001) : Effect of isoproturon pretreatment on the blochemical toxicodynamics of anllofos in male rats. Toxdcology 165,87-95.

Finson. J. A; Roberts, D. W. and James, L. P. (2010) : Mechanisms of acetamlnophenInduced liver necrosis. Handb Exp Phamacol. 196.369-405.

Isblster, G. K.; O'Regan, L.; Blbbritt, D. and Whyte, I. M. (2004) : Alprazolam is relatively more toxic than other benzodlazepines in overdose. Br $\mathrm{J}$ Clin Pharmacol, 58,88-95.

Larsen. K. (1872) : Creatinlne assay by a reaction - kinetic principle. Clin chem. Acta. 41 . 209- 217 .

Leuftens, T. R. M.; Vermeeren, A, Smink, B. E.; van Ruitenbeek, P. and Framaekers, J. G. (2007) : Cognitive, psychomotor and actual driving performance in healthy voluntecrs after Imrnediate and extended: release formulations of alprazolam Img. Psychopharmacol, 191. 951-959.

Maitra, S.; Saha, B.; Santra, C. R.; Mukherjee, A. Goswaml, S.; Chanda, P. K. and Karmakar, P. (2007) : Alprazolam induced conformational change in hemoglobin.Int $J$ Biol Macromolccules 41. 23-29.

Meador, K. J. (1984) : Cognitive side effects of antieptleptic drugs. Car J Neurol Sci.; 21(3):S12-16. 85.

Mohamed, A. A.; Abo-Amou, D. E.; Shehata, M. A and El-Ashery, N. E. (2001) : Glutathione peroxddase and nltric oxide tn paHents with chronic liver diseases. Egypt $J$ Schistosomlasis Infect Endem DIs.23.27-46.

Morox G. (2004) : High-potency benzodiazcpines: recent clinical results. J Clin Psychlatry, 65(Suppl 5), 13-18.

Moshage, H.; Kok. B.; Hulzenga, J. R. and Jansen, P. L. (1995) : Nitrte and nitrate determination in plasma :a critical cvaluation. Clin Chem ,41,892-896.

Pardo, H. G.: Conejo, N. M. and Arlas, J. L. (2008) : Oxddative metabolism of limblc structures after acutc administration of 
diazepam, alprazolam and zolpidem. Prog Neuro-Psychopharmacol Blol Psychlatry 30. 1020-1026.

Rosalki, S. B. (1967) : An improved procedure for serum creatune phosphokinase determination. J Lab Clin Med, 69,696-705.

Saha, B.: Mukherjee, A.: Santra, C. R.; Chattopadhyay, A.; Ghosh, A. N.; ChoudhuH, U. and Karmakar. P. (2009a) : Alprazolam intercalates into DNA. J Biomolecul Structure Dynamics 26, 421-429.

Baha, B.: Mukherjee, A. Samanta, S.; Saha, P.; Ghosh, A. K.; Santra, C. R. and Karmakar, P. (2009b) : Caffeline augments Alprazolam induced cytotoxdclty in human cell lines. Toxdcol in Vitro, 23, 1100-1109.

Bayed-Ahmed, M. M.; Khattah, M. M.; Gad, M. Z. and Osman, A. M. (2001) : Increased plasma endothelin-l and cardiac nitrlc oxide during doxorubleln-Induced cardiomyopathay. Pharmacol Toxdcol. 89. 140144.

Schmidt, E. and Schmidt, F. W. (1981) : Kline Enzyrne Flebel Sehriftenselhe. Dlagnosuc Boehringer Mannheim, $3^{\text {rd }}$ ed.

Shaw, L. M.; Stromme, J. H.; London, J. and Odorsen, L. (1083) : International Federation of Clinical Chemistry. Selentinc cominittee, Analytical Seetion. Expert panel on Enzymes. IFCC methods for measurement of enzymes. Part 4. IFCC methods for gamma glutamyl transferase lgamma - glutamyl] peptdde : amino actd gamma. Clin Chem Aeta 135 (3) : $315 \mathrm{~F}-338 \mathrm{~F}$.
Silverberg. D. 8.; Wexler, D.; Palazzuoll, A; lalna, A and Schwartz, D. (2009) : The anemia of heart fallure. Acta Haematol, 122. 109-19.

Skegg DCG. (2001) : Evaluating the safety of mediclnes. with particular reference to contraception. Stat Med:20:3557-69.

Tsakiris, S. and Dllconstantinos, G. (1984) : Innuence of phosphatddylsertne on $\mathrm{Nat} / \mathrm{K}+$ stimulated ATPase and acetylchollnesterase actultues of dog brain symaptosomal plasma membranes. Blochem J, 22, 301307.

Verster, J. C. and Volkerte, E. R. (2004) : Clinieal pharmacology, cllnical efficacy, and behavioral toxiclty of alprazolam : a review of the 1tterature. CNS Drug Rev 10:4576.

Vlctor, V. M.; Apostolova, N.; Herance, R.; Hernandez-Mdjares, $A$ and Rocha, M. (2009) : Oxddative stress and mitoehondral dysfunction in atheroselerosis: mitochondratargeted antjoxidants as potential therapy. Curr Med Chem, 16,4654-67.

Weingtcin, D. M.; Mihm, M. J. and Bauer J. A. (2000) : Cardiac peroxynitrite formation and left ventrical dysfunction following doxorubicin treatment in miee.J Pharmacol Exp Ther, 294,396-401.

Woodcock, A. A; Gross, E. R. and Geddes D. M. (1981) : Drug treatment of breathlessness: contrasting effects of diazepam and promethazime in pink puffers. BMJ (Clin Res Ed), 283(6287),343-6. 
Zhang, X.; De Sllva, D.; Sun, B.: Flsher, J.; Bull, R. J.: Cotruvo, J. A and Cummlogs, B. S. (2010) : Cellular and molecular mechanisms of bromate-Induced cytotoxdcity In human and rat kidney cells. Toxdcology. 2010 Jan 12. 


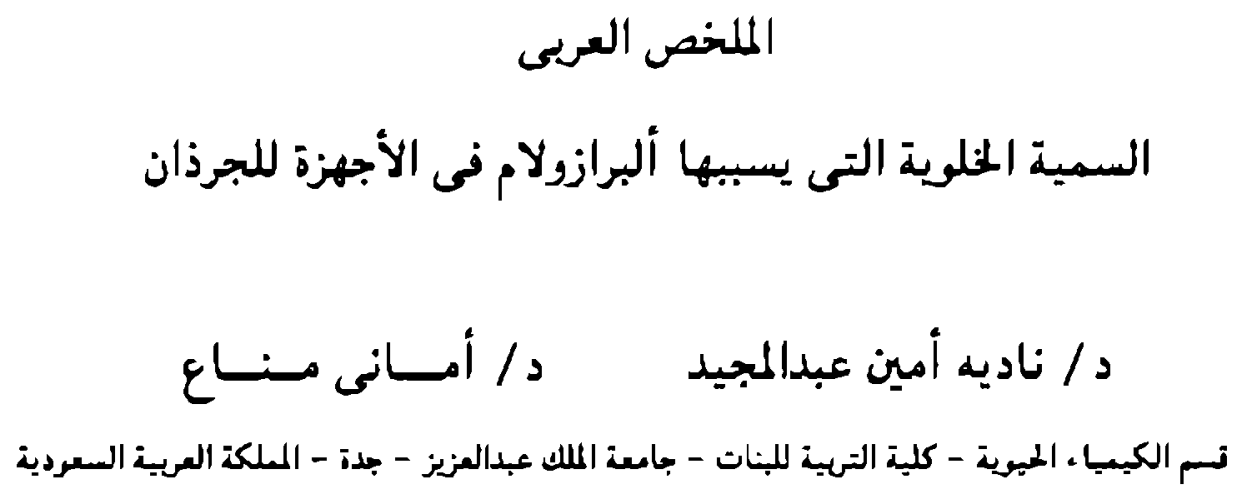

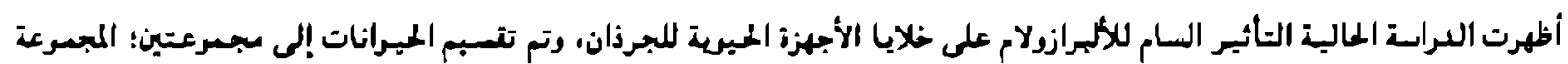

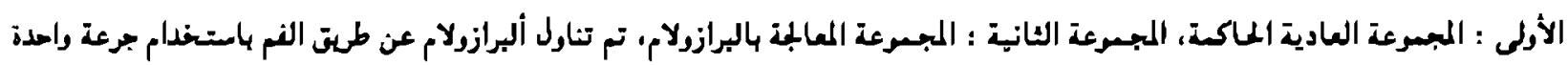

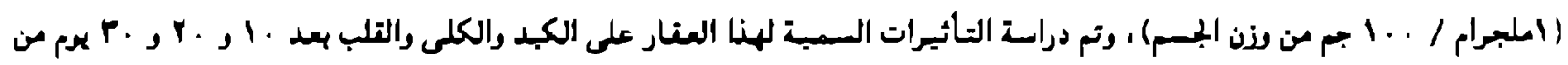
تنارل هنا العقار.

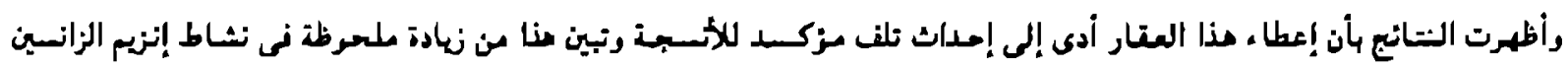

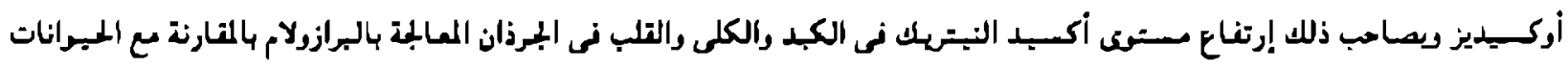

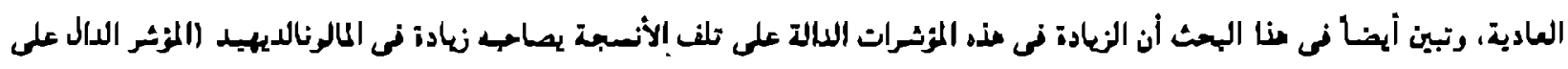

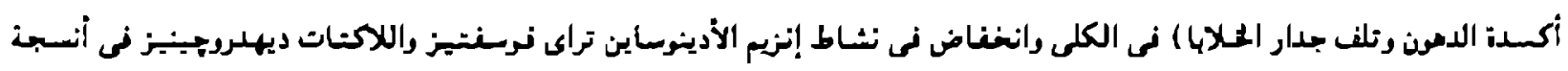

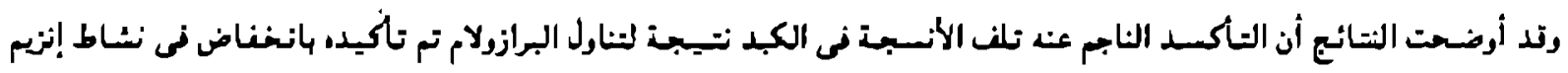

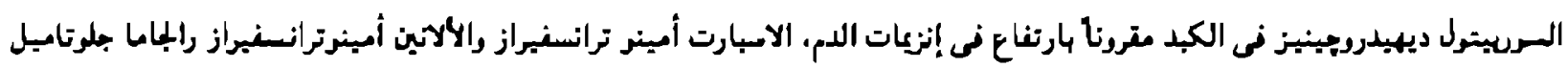

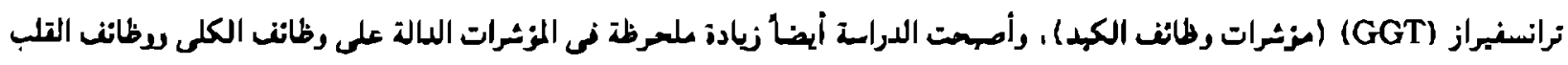

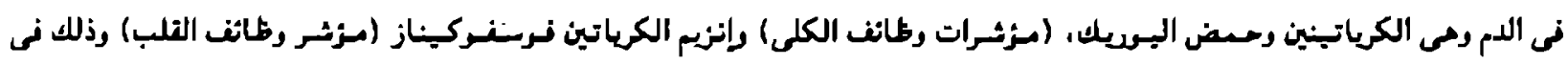

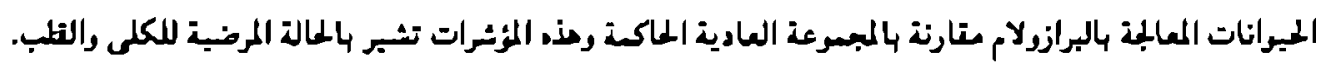

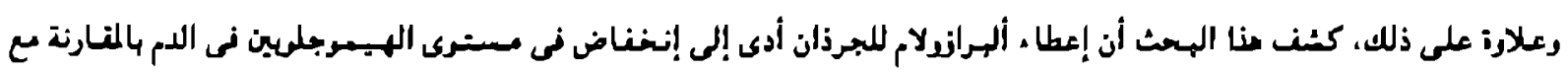

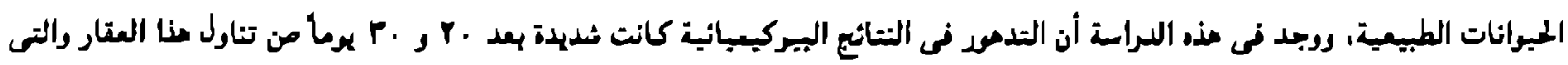

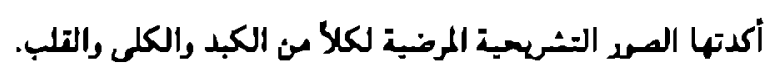
الكلمات المناعية : ألبرازرلام - السمية العلمية - أضرار بالانسبة - الصرد التشريسية المرضية - رالإنزيمات. 